\title{
Impact of Monetary Policy (Interest Rate) Regimes on the Performance of the Banking Sector in Nigeria
}

\author{
${ }^{1}$ Ndubuaku Victor C., ${ }^{2}$ Ifeanyi Ozioma., ${ }^{3}$ Nze Chiaka, ${ }^{4}$ Onyemere Samuel. \\ ${ }^{1,2,3,4}$ Department of Accountancy, Federal College of Agriculture Ishiagu, Ebonyi State, Nigeria.
}

\begin{abstract}
This paper examined the impact of monetary policy regimes on the performance of ommercial banks in Nigeria. The paper used Descriptive and Ex-post Facto Research Design. It utilized time series data collected from Central Bank of Nigeria Bulletin. The study was divided into SAP Period (1986-1999) and Post SAP Period (2000 -2013). Eight Research Questions and eight Hypotheses were raised for the study. Regression and Pearson Product Moment Correlation technique were used to analyze the data collected while t-test statistic was employed in testing the hypotheses. Monetary Policy Rate was the independent variable while Total Assets Value, Deposit Mobilization, Loans and Advances and Credit to the Private Sector were the dependent variable in different regression equations. The study discovered that Monetary Policy Rate during the SAP Period did not have significant impact on the Total Assets Value, Deposit Mobilization, Loans and Advances and Credit to the Private Sector while Monetary Policy Rate during the Post SAP Period had significant impact on the Total Assets Value, Deposit Mobilization, Loans and Advances and Credit to the Private Sector respectively. The paper recommended that policy makers should administer the Monetary Policy instruments to ensure they are effective in generating and stimulating the desired level of economic activity in the banking sector. It further recommended that political interferences which distort the performance in the banking industry be minimized.
\end{abstract}

\subsection{Background of the Study}

\section{Introduction}

Commercial Banks are custodians of depositor's funds and operate by receiving cash deposits from the general public and loaning them out to the needy at statutorily allowed interest rates (Ngure, 2014). In Nigeria the financial sector is dominated by commercial banks, therefore any failure in the sector has a grave consequence on the economic growth and development of the country. This is due to the fact that any bankruptcy that could happen in the sector has a contagion effect that can lead to bank runs, crises and bring overall financial crisis and economic tribulations (IMF, 2001). Banks play a major role in the economy through their economic function of financial intermediation that performs both a brokerage and a risk transformation function (Hara, 1983). Commercial Banks as financial intermediaries perform financial intermediation function of mobilization and allocation of funds from the economic surplus (lenders) to the economic deficit unit (borrowers). This function is directly linked with banks profitability which encourages economic growth. According to Wainaina (2013), profitability of banks has relationships with growth and development of the economy. Deposit money banks are the most important savings and mobilization of financial resources and allocating them to productive investment and in return promote their performance (Victor 2013). Interest rate however plays a vital role in how a bank makes money (Haye, 2013). Hualan (1992) found that interest rate is one of the most important factors that affect the bank financial performance. Interest rates are the reward paid by a borrower (debtor) to a lender (creditor) for the use of money for a period and they are expressed in a percentage, per annum (pa) to make them comparable. Interest rates are also quite often referred to as the price of money. Corb (2012) described interest rate as an economic tool used by the Central Bank to control inflation and boost economic development. Therefore poor decisions on an interest rate regime could spell doom for the financial system and the economy as a whole. The Central Bank of Nigeria uses the interest rate is as a monetary policy tool to adjust the lending rates of banks and other financial institutions in Nigeria. Giovanni (2006) argued that high interest rate set by the Central Bank means that the other financial institution will have to charge high because they are all profit oriented. In Nigeria, since the inception of interest rates deregulation in 1986, the government has pursued a market-determined interest rate regime, which does not permit a direct state intervention in the general direction of the economy (Adebiyi and Babatope, 2004). Rasheed (2010) states that the Nigerian economy saw different interest rates for different sectors in 1970's through the mid 1980 (regulated Regime). Preferential interest rates were therefore applied to encourage priority sectors such as agriculture and manufacturing.

The establishment of the African Banks Corporation (ABC) now First Bank and establishment of other banks gave rise to the emergence of lending activities of banks. The lending practice of the colonial banks which granted loans discriminately to foreigners gave rise to the agitation of indigenous banks. This was not without its attendant challenges. The government thereby introduced a regulated interest rate regime. The introduction of 
SAP thereby relaxed many of the stringent procedures. Okafor (2011) identified five major reform cluster periods namely; pre and post-Independence era (1958-1969), indigenization era (1970-1976), Okigbo Committee era (1977-1985), SAP era (1986-1999), and Democracy or fourth republic era (2000-2010). However the banking industry is presently regulated by the Banks and other Financial Institutions Act (2004 as amended). In light of this, the study tends to highlight the impact of Monetary Policy (interest rate) regime on banks performance in Nigeria during the SAP era (1986-1999), and Democracy or fourth republic era (20002010) and make comparison. However, the Democracy or fourth republic era (2000-2010) has been modified (for this study) as Post SAP Era (2000-2013).

\subsection{Statement of the Problem}

Commercial banks in Nigeria are predominant in the banking industry. Their loans and credits form a major portion of the total credit to the private sector. However, they still face major challenges with regards to government regulations, institutional difficulties and other similar challenges. This study therefore intends to identify the impact of the monetary policy tools on the performance of the banking industry. This would be of great assistance to the regulators in forming a favourable interest rate regime that would meet the macro economic objectives in Nigeria.

\subsection{Research Questions}

1a. Did Monetary Policy Interest Rate have any significant impact on Total Asset Value of Commercial Banks during the SAP period.

1b. Did Monetary Policy Interest Rate have any significant impact on Total Asset Value of Commercial Banks during the P-SAP period.

2a. Did Monetary Policy Interest Rate have any significant impact on Deposit Mobilization of Commercial Banks during the SAP period.

2b. Did Monetary Policy Interest Rate have any significant impact on Deposit Mobilization of Commercial Banks during the P-SAP period.

3a. Did Monetary Policy Interest Rate have any significant impact on Loans and advances of Commercial Banks during the SAP period.

3b. Did Monetary Policy Interest Rate have any significant impact on Loans and advances of Commercial Banks during the P-SAP period.

4a. Did Monetary Policy Interest Rate have any significant impact on Commercial Banks' Credit to the Private Sector during the SAP period.

4b. Did Monetary Policy Interest Rate have any significant impact on Commercial Banks' Credit to the Private Sector during the P-SAP period

\subsection{Objective of the Study}

Gilchris, (2013) states that although it is difficult to determine the direction of the relationship between interest rates and profitability, studies confirm that interest rates instability affects Commercial Banks' financial performance while other studies give contradictory findings. In light of this, the study investigated the impact of the monetary policy regime on financial performance of Commercial Banks in Nigeria.

The study therefore sought to establish:

1. Whether Monetary Policy Interest rate significantly influenced Total Asset Value during the different interest rate regimes.

2. Whether Monetary Policy Interest rate significantly influenced Deposit Mobilization during the different interest rate regimes.

3. Whether Monetary policy Interest rate significantly influenced Loans and Advances during the different interest rate regimes.

4. Whether Monetary Policy Interest Rate significantly influenced Credit to the Private Sector during the different interest rate regimes.

\subsection{Hypothesis of the Study}

This defines the relationship between relevant variables involved in the study. They are tentative statements that require testing. They are stated in the null hypothesis.

H1a. There is no significant relationship between Monetary Policy Interest Rate and Total Asset Value of Commercial Banks during the SAP period.

H1b. There is no significant relationship between Monetary Policy Interest Rate and Total Asset Value of Commercial Banks during the P-SAP period.

H2a. There is no significant relationship between Monetary Policy Interest Rate and Deposit Mobilization of Commercial Banks during the SAP period. 
H2a. There is no significant relationship between Monetary Policy Interest Rate and Deposit Mobilization of Commercial Banks during the P-SAP period.

H3a. There is no significant relationship between Monetary Policy Interest Rate and Loans and advances of Commercial Banks during the SAP period.

H3b. There is no significant relationship between Monetary Policy Interest Rate and Loans and advances of Commercial Banks during the P-SAP period.

H4a. There is no significant relationship between Monetary Policy Interest Rate and Loans and advances of Commercial Banks during the SAP period.

H4b. There is no significant relationship between Monetary Policy Interest Rate and Loans and advances of Commercial Banks during the P-SAP period

\subsection{Scope of the Study}

The research studied Monetary Policy (interest rate) regimes of the SAP (Structural Adjustment Programme) and P-SAP (Post-Structural Adjustment Programme) or the Democracy Period. Okafor (2011) identified five major reform cluster periods namely; pre and post-Independence era (1958-1969), indigenization era (1970-1976), Okigbo Committee era (1977-1985), SAP era (1986-1999), and Democracy or fourth republic era (2000-2010). Therefore, this study covers The SAP and P-SAP period of covers 1986-1999 and 2000-2013 respectively. Other interest rate variables could have been studied but due to limitation of time and other resources, the study is limited to the Monetary Policy Rate of the Central Bank of Nigeria and its effects on Loans and advances, deposit mobilization, credit to the private sector during the SAP and P-SAP period.

\subsection{Significance of the Study}

The study helps us understand the impact of an effective monetary policy regime on the performance of the Commercial Banks. It would aid the regulators to carefully plan and forecast the effects of its policies to meet its objectives of economic growth and full employment. To bankers, it would expose the relationship existing between our relevant variables, which will be of interest to them in their respective banks. This would also benefit the academic community which would avail them the opportunity of conducting further research in the topic of similar areas.

\subsection{Operational Definition of Terms}

\subsubsection{Financial Performance}

Financial Performance analysis refers to analytical tools to measure the strength and weakness of a firm in relation to its balance sheet and profit and loss statement. Examples of bank financial performance tools and ratios include operating income, earnings before interest and taxes, Total Asset value. Financial performance analysis is carried out to ascertain the profitability position and performance of a firm. It can be conducted by management, owners, creditors, investors as demonstrated by Chenn (2011).

\subsubsection{Monetary Policy Rate (MPR)}

Minimum Rediscount Rate (MRR) now known as Monetary Policy Rate (MPR) was used to signal the desired direction of interest rate movement (Nwude, 2013).

\subsubsection{Deposit Mobilization}

Deposit Mobilization measures the aggregate mobilization of deposits in the economy. Deposits are bank accounts that allow the owner of the account (creditor) to make demand on banks. They include demand, time and savings and money market deposit account.

\subsubsection{Credit to the Private Sector}

Domestic credit to private sector by banks refers to financial resources provided to the private sector by other depository corporations (deposit taking corporations except central banks), such as through loans, purchases of non-equity securities, and trade credits and other accounts receivable, that establish a claim for repayment. For some countries these claims include credit to public enterprises (IMF, 2016).

\subsubsection{Loans and Advances}

Loans refers to a debt provided by a financial institution for a certain period while Advances are the funds provided by the banks, which needs to be payable within one year 


\subsection{Introduction}

\section{Literature Review}

This chapter focuses on the conceptual framework, theoretical and empirical framework. It ends with a review summary.

\subsection{Conceptual Framework}

\subsubsection{Interest Rates}

Gilchris, (2013) states that although it is difficult to determine the direction of the relationship between interest rates and profitability, studies confirm that interest rates instability affects Commercial Banks' financial performance while other studies give contradictory findings. The Central banks also lends Commercial Banks funds. Money borrowed from the Central Bank is to be repaid at a particular interest rate (Monetary Policy Rate). This makes interest rate a powerful government regulatory tool for determining other interest rates in the banking industry. Hualan (1992) stated that interest rate is one of the most important factors that affect the bank financial performance. Corb (2012) argued that interest rate is an economic tool used by the Central Bank to control inflation and to boost economic development. Ngugi (2004) explained that low interest rates and small spread promote economic growth in big ways hence encouraged. Crowley (2007) and Ngure (2014) defined interest rates as the price a borrower pays for the use of money they borrow from a lender (financial institution) or fee paid on borrowed assets. Sayedi (2013) expressed interest rate as the percentage rate over a period of one year. Karl et al., (2009) posits that interest rates are derived from macroeconomic factors which agree with Irungu (2013) that interest rates are major economic factors that influence the economic growth in an economy. Inflation and inflationary expectations can press interest rate upward which affects lending rates resulting to reduce credit demand and lending ability of Commercial Banks (Keynes, 2006). Irungu (2013) states that interest rate is the price of money. Interest rates can either be nominal or real. Nominal interest rate can be measured in naira terms, not in terms of goods. The nominal interest rate measures the yield in naira per year, per naira invested while the real interest rate is corrected for inflation and is calculated as the nominal interest rate minus the rate of inflation (Pandey,1999).

\subsubsection{Bank Profitability and Financial Performance}

The profitability of a bank is determined by interior and exterior determinants (Sattar, 2014) which agrees with (Ongore, 2013; Al-Tamini et al., 2010). The interior determinants are called micro or bank specific determinants of profitability because they are initiated from bank accounts like balance sheet or profit and loss account. While on the other hand, the exterior determinants are the variables which are not in the control of banks' management such as monetary policy interest rates. Chen et al. (1986) explained that these macroeconomic factors are significant in explaining firm performance (profitability) and subsequent returns to investment. Gilchris, (2013) agrees that the financial performance is commonly measured by ratios such as Return on Equity, Return on Assets. There are many different mathematical measures to evaluate how well a company is using its resources to make profit (Irungu, 2013). Financial performance can be measured using the following techniques; operating income, earning before interest and taxes, net asset value (Gilchris, 2013). Irungu (2013) described financial performance analysis as the process of identifying the financial strengths and weakness of the firm by properly establishing the relationship between the items of the balance sheet and profit and loss account. It's the process of identifying the relationship between the component parts of financial statements to ascertain an organization position, performance and prospects. Financial performance analysis can be undertaken by management, owners, creditors, investors (Chenn, 2011). Quarden (2004) argued that financial performance analysis helps in short term and long term forecasting and growth and can be identified with the help of financial ratios such as asset Utilization/efficiency ratios, deposit mobilization, loan performance, liquidity ratio, leverage/financial efficiency ratios, profitability ratios, solvency ratios and coverage ratios can be used to evaluate bank performance (Bekant, 2011). The performance of banks gives direction to shareholders in their decision making (Panayiotis et al., 2006). Wainaina, (2013) says the effect of macroeconomic factors in other sectors of the economy will always affect the banking sector and what goes on in the banking sector will affect the other sectors of the economy. Chen et al., (1986) maintains that these macro-economic factors are significant in explaining firm performance (profitability) and subsequent returns to investors. Gilchris (2013) agrees that financial performance is commonly measured by ratios such as return on equity, return on assets, return on capital, return on sales and operating margin. A firm has several objectives but profit maximization is said to be paramount among these (Damilola, 2007; KPMG, 2005; Raheman and Nasr, 2007). Profit is a tool for efficient resources allocation because it is the most appropriate measure of corporate performance under competitive market conditions (Pandey, 2005). Conceptually profit connotes the excess of revenue generated by a firm over its associated costs for an accounting period. Operationally the term profit is imprecise, as many variants exist. The term profit could refer to profit before tax, profit after tax, gross profit, net profit, profit per share, return on assets, among other variants (Damilola, 2007; Pandey, 2005). This imprecision has often posed decisional challenges to researchers who must select an appropriate variant to proxy profitability. However, the 
most commonly used variants as appropriate measure of profitability include Gross operating profit, Net operating profit, Return on Assets (Deloof, 2003; Teruel and Solano, 2006; Lazaridis and Tryfonidis, 2005; Raheman and Nasr, 2007). According to Okafor (2011) the profitability performance also can be accessed from both book value and market value perspectives.

\subsubsection{Effect of Interest rate on Financial Performance}

Financial performance is an indicator of how profitable a company is relative to its total assets (Irungu, 2013). Financial performance can be measured by Return on Asset (ROA). ROA is measured by dividing the net income by average total assets. Return on Assets formula looks at the ability of a company to utilize its assets to gain a net profit (Kiarie, 2011). Both the IMF report and Federal Reserve paper suggests possible effects of interest increases to net interest margin, balance sheet structure and values of interest sensitive assets and liabilities. If there is a steeping of the yield curve, the net interest margin would be expected to increase. Higher interest rate can result in slower economic growth and development because of high capital costs and defaults by individuals and firms who borrow from banks (Papa, 2014). Interest rates impact bank earnings through net interest margins/ net interest income which is a key factor driving bank earnings and stock performance (Hayes, 2013). When rates rise, banks NIM/NET 11 tend to decline and vice versa. Interest rates are also a key driver of loan yields (Hayes, 2013). Loan yields are generally from market interest rate. Higher rates at a measured pace are generally a positive for banks given the uplift to asset yield, deposit margin, along with generally improving macro conditions. Unexpected movements in rates and the yield curve can be negative for banks balance sheet, more specially, result in unrealized losses in accumulated other comprehensive income.

\subsection{Theoretical Framework}

The Theoretical framework is guided by the work of Bekaert (1998) which tries to analyze the influence of interest rates on bank performance. This section considers theories such as loan Pricing theory, firm characteristic theory, theory of multiple lending, the signaling approach, credit market theory, classical theory of interest.

\subsubsection{Loan Pricing Theory}

Banks cannot always set high interest rates. Banks should consider adverse selection and moral hazard because it is difficult to determine the borrower type at the start of the banking relationship (Stiglitz and Weiss, 1981). If interest rates are too high, it might cause adverse selection problems because only high risk borrowers are willing to borrow. Once they receive the loans they may develop moral hazard behavior since they are likely to take highly risky projects (Chodecai, 2004)

\subsubsection{Loanable Funds Theory}

This theory synthesizes both the monetary and non monetary impact of the problem (saving and investment process) (Wensheng, et al., 2002). It assumes that interest rates are determined by supply of loanable funds and demand for credit. It recognizes that money can play a disturbing role in the saving and investment processes and thereby causes variations in the level of income. The theory suggests that interest rates equate the demand and supply of loanable funds. Loanable funds are the sum of money supplied and demanded at any time in the money market. Loanable funds theory has implications on banks savers and borrowers and each side is well compensated at equilibrium, Interest rate should be structured in a way every party feel comfortable (Emmanuelle, 2013)

\subsubsection{Classical Theory of Interest}

According to Keynes, the classical theory of interest is the savings-investment theory. It states that on the general equilibrium theory, the rate of interest is determined by the intersection of demand for and supply of capital which agreed with Caplan (2000). Fredman (1991) explains that the saving and investment are the two real factors determining the rate of interest.

\subsubsection{Rational Expectations Theory of Interest Rates}

This is based on the idea that people formulate expectations based on all the information that is available in the market. It holds that the best estimation for future interest rates is the current spot rate and that changes in interest rates are primary due to unexpected information or changes in economic factors. The limiting factors of rational expectation theory are mostly related to the difficulty in gathering information and understanding how the public uses its information to form its expectation (Caplan, 2000). If interest rate rise will avoid borrowing, this in turn will affect bank performance and vice versa (Bekaert,1998) 
Impact of Monetary Policy (Interest Rate) Regimes on the Performance of the Banking Sector ..

\subsubsection{Firm Characteristics Theories}

These theories predict that the number of borrowing relationships will be decreasing for small high quality, information opaque and constraint firms, all other things being equal (Godlewski and Zaine, 2008)

\subsubsection{Credit Market Theory}

It states that the term of the credit clears the market. If collateral and other restrictions remain constant, interest rate is the only price mechanism. If there is an increasing demand for credit and the supply remains constant, the interest rate rises and vice versa. Ewert (2000) suggest that the higher the failure risk of the borrower, the higher the interest premium.

\subsubsection{Multiple Lending Theory}

The theory posits that banks should be less inclined to share lending (loan syndication) when the equity markets are well developed. Mergers, acquisition and outside equity increase banks' lending capacity and reduces the need for greater diversification and monitoring (Carletti, 2006; Ongene and Smith, 2000; Karceski, 2004; Degryse, 2004).

\subsubsection{The Signalling Arguments}

This theory posits that a good company should provide more collateral so they can signal an assurance to banks that they are less risky borrowers which would in turn cause lower interest rates. Also, on the reverse signal argument, banks only require collateral and or covenants for relatively risky firm that also pay higher interest rates (Chodeschai, 2004; Ewert and Schenk 1998).

\subsubsection{Macroeconomic Theory}

The theory was proposed by Friedman, (1963). The theory views interest rates as always and everywhere a monetary phenomenon (Friedman, 1963). Further, macroeconomic theory assumes that growing the money supply in excess of real growth causes interest rates to rise. This is also the result from the Harberger (1963) model, which assumes that prices adjust to excess money supply in the money market. It is on the basis of this assumption that it is possible to invert the real money demand and control interest rates. Interest rates volatility in open economies results from different disequilibria in many markets specifically, the domestic money market, external/foreign markets and the labour market. Thus increase in interest rates emanates from three main sources that include excess money supply, foreign prices and cost push factors (Were et al., 2013). The theory is related to keynesian liquidity preference theory but recognizes additional sources of interest rates not only demand for money but also foreign prices and cost push factors.

Critics of this theory base their argument on the grounds that governments would in practice be unlikely to implement theoretically optimal policies. According to them, the implicit assumption underlying the macroeconomic revolution was that economic policy would be made by wise men, acting without regard to political pressures or opportunities, and guided by disinterested economic technocrats. They argued that this was an unrealistic assumption about political, bureaucratic and electoral behaviour. In relevance to the study, macroeconomic theory views growing money supply in excess of real growth as the cause of interest rates to rise. Interest rate volatility is seen by the theory as emanating from three main sources that include excess money supply, foreign prices and cost push factors. Interest rates volatility will also results from different disequilibria in many markets specifically, the domestic money market, external/foreign markets and the labour market. Hence controlling interest rates volatility will involve dealing with disequilibrium in the markets (Ngure, 2014)

\subsubsection{Keynes's Liquidity Preference Theory}

The theory was proposed by Keynes (2006). According to the liquidity preference theory, the interest rates are determined by the demand for and supply of money balances. The theory assumes that people's demand for money is not for transactions purpose but as a precaution and for speculative purposes. The transaction demand and precautionary demand for money increase with income, while the speculative demand is inversely related to interest rates because of the forgone interest. The supply of money is determined by the monetary authority (the central bank), by the lending of Commercial Banks and by the public preference for holding cash (Were et al., 2013).

Therefore, interest rates are expected to increase as the maturity profile of securities increases. This is so because the longer the maturity, the greater is the uncertainty; and therefore the premium demanded by investors to part with cash increases as the maturity profile increases.

Consequently, current interest rates reflect expected inflation rates, income (GDP) and expected money supply changes (Were et al., 2013). 
Critics of this theory argue that the liquidity preference theory of interest suffers from a fallacy of mutual determination. Keynes alleges that the rate of interest is determined by liquidity preference. In practice, however, Keynes treats the rate of interest as determining liquidity preference. The critics state that "The Keynesians therefore treat the rate of interest, not as they believe they do- as determined by liquidity preferencebut rather as some sort of mysterious and unexplained force imposing itself on the other elements of the economic system (Were et al., 2013).

In relevance to the study, the theory views interest rates as being mainly driven by the liquidity level in the economy. The theory does not recognize the role of macroeconomic policies formulated by the central bank but interest rates are purely driven by the demand of money in the economy. Therefore, interest rates will go up and down according to the level of liquidity in the economy and preference for the liquidity by the users of funds (Ngure, 2014).

\subsection{Empirical Review}

Gertler and Gilchrist (1994) conducted a study that specifically looked at how bank business lending responds to monetary policy tightening. They found that banks' lending does not decline when policy is tightened. They concluded that the entire decline in total lending comes from a reduction in consumer and real estate loans. In contrast to Gertler and Gilchrist (1994) study, Kashyap and Stein (1995) found evidence that banks' lending may respond to a tightening of monetary policy. They found that when policy is tightened, both total loans and business loans at small banks fall, while loans at large banks are unaffected. The differential in the response of small banks may indicate they have less access to alternative funding sources than large banks and so are less able to avoid the loss of core deposits when policy is tightened.

Amidu and Wolfe (2008) examined the constrained implication of monetary policy on bank lending in Ghana between 1998 and 2004. Their study revealed that Ghanaian banks' lending behaviour is affected significantly by the country's economic support and change in money supply. Their findings also support the finding of previous studies that the Central Bank prime rate and inflation rate negatively affect bank lending. Prime rate was found statistically significant while inflation was insignificant. Based on the firm level characteristics, their study revealed that bank size and liquidity significantly influence bank's ability to extend credit when demanded.

Gavin (2010) studied the factors affecting banking sector interest rate spread in Kenya. The study sought to investigate the factors responsible for interest rate spread in Kenya Commercial Banks. The study adopted a descriptive and quantitative research design on a sample of 15 Commercial Banks in Kenya which accounted 85 percent of all the loans disbursed between 2002 and 2009. The study used secondary data obtained from the banking survey publication. The study found out that capital adequacy ratio, treasury bills rate and discount rate have a significant impact on interest rate spreads.

Ngugi and Kabubu (1998) studied financial sector reforms and interest rate liberalization. It aimed at exploring the sequencing and actions taken in the liberalization process in Kenya. The study investigated the interest rate levels, spreads and determining factors as an indicator too financial performance in response to the process. The sample size was 20 banks in Kenya. The data source included the Central Banks reports. It found that the financial system was still characterized by repression factors such as negative interest rates, inefficiency and underdeveloped financial markets.

Felicia (2011) studied the determinants of Commercial Banks' lending behavior in the Nigerian context. The study aimed to test and confirm the effectiveness of the common determinants of Commercial Banks' lending behavior and how it affects the lending behavior of Commercial Banks in Nigeria. The model regressed the Commercial Banks loan advance with other determinant variable such as Volume of Deposits (Vd), Investment Portfolio (Ip), Lending Rate (Ir), Stipulated Cash Reserve Ratio (Rr) and Liquidity Ratio (Lr) for the period 1980-2005. The model hypothesizes there is a functional relationship between the dependent and independent variables and were found to have a significant relationship.

Nwakanma (2013) examined the impact of interest rate reform on the financial intermediation function of the Commercial Banks in Nigeria using the dummy variables approach to Chow test for structural stability. The cointegration and error correlation model were used to capture both the long run and the short run dynamics. The empirical results reveal that though the intermediation function of the Commercial Banks has significantly improved as a result of the deregulation of interest rates, it has not translated into improved standard of living of the populace as the incidence of poverty is still on the increase. Also the results show that lending rates do not influence demand for domestic credits in Nigeria unlike deposit rates which proved to be a major determinant for the amount of credit extended by the Commercial Banks. They concluded that though interest rates deregulation has improved credit extension to the domestic economy, the link between interest rates, domestic credit extension and economic growth is not automatic. They recommended a partial deregulation of interest rates that will ensure concessionary interest rates to the productive sector of the economy. 
Udeh (2015) examined the impact of monetary policy instruments on profitability of Commercial Banks in Nigeria using the Zenith Bank Plc experience. The study utilized descriptive research design using time series data collected from published financial statements of Zenith Bank Plc and Central Bank of Nigeria Bulletin from 2005 to 2012. The study used Pearson Product Moment Correlation technique to analyze the data collected while t-test statistic was employed in testing the hypotheses. They discovered that cash reserve ratio, liquidity ratio and interest rate did not have significant impact on the profit before tax of Zenith Bank Plc. However, minimum rediscount rate was found to have significant effect on the profit before tax of the bank. The paper concluded that a good number of monetary policy instruments do not impact significantly on profitability of Commercial Banks in Nigeria

Okoye and Eze (2013), examined the impact of bank lending rate on the performance of Nigerian Deposit Money Banks between 2000 and 2010. It specifically determined the effects of lending rate and monetary policy rate on the performance of Nigerian Deposit Money Banks and analyzed how bank lending rate policy affects the performance of Nigerian deposit money banks. The result confirmed that the lending rate and monetary policy rate have significant and positive effects on the performance of Nigerian deposit money banks. The implication of this is that lending rate and monetary policy rate are true parameter of measuring bank performance. The results agreed with Udeh (2015) that minimum rediscount rate was found to have significant effect on the profit before tax of the bank.

Enyioko (2012) examined the performance of banks in Nigeria based on the interest rate policies of the banks. The study investigated 2 Nigerian banks. Regression and error correction methods were used to analyze the relationship between interest rate and bank performance. The study found that interest rate policies have not improved the overall performances of the banks significantly.

\subsection{Literature Summary}

Most of the literature on bank performance has focused on sector specific factors that affect the banking sector performances or determinant of bank performance. Yet little has been done on the Monetary Policy Interest Rates and its effects on the bank performances in Nigeria. There also seen to be a lot of study in other regions. Therefore this study seeks to bridge this gap.

\section{Research Methodology}

This chapter outlines the research design and methodology that was applied in conducting this study. It describes the research design, population of the study, sample size, sample frame, data collection methods and data analysis and presentation of the research.

\subsection{Research Design}

The research design employed Descriptive and Ex-post facto Research Design. Descriptive research design method helps in gathering information about the existing status of the phenomena in order to describe what exists in respect to variables. According to Coopers and Schindler (2008) descriptive studies are more formalized and typically structured with clearly stated hypotheses or investigative questions. This method is used because it addresses the objective of the study in investigating the relationship between the variables of the study. (Kothari, 2008). Regression and correlation analysis was used to determine the relationship between Monetary Policy Interest Rate and Performance of Commercial Banks. The study used time series data.

\subsection{Population and Sample of the Study}

The target population for this study was all Commercial Banks in Nigeria. There were 24 Commercial Banks in Nigeria as at December 30, 2013 (CBN, 2013). All the 24 banks constituted the study sample.

\subsection{Data Collection Techniques}

The data required for the study was obtained from secondary sources that were used to investigate the relationship between dependent and independent variables. The study used secondary data sources to gather information relevant to the research objectives. The study covered data for SAP period (1986-1999) and P-SAP period (2000-2014). The secondary data were collected from the Central Bank of Nigeria; website and statistical bulletin, annual reports and the internet.

\subsection{Model Specification}

The theoretical foundation is based on the study of Okoye and Eze (2013) and Udeh (2015), who used Pearson Product moment correlation technique to analyze the data collected while t-test statistic was employed in testing the hypotheses.

\subsubsection{Conceptual Model}

The following function shows the mathematical relationship between the dependent and independent variable. Model

1a. $\quad \mathbf{T A V}_{\mathrm{SAP}}=\mathbf{f}(\mathbf{M P R})$ 

1b. $\quad T A V_{P-S A P}=\mathbf{f}(M P R)$
2a. $\quad \operatorname{DpM}_{\mathrm{SAP}}=\mathbf{f}(\mathrm{MPR})$
2b. $\quad$ DpM $_{P-S A P}=\mathbf{f}($ MPR $)$
3a. $\quad$ LAd $_{\text {SAP }}=\mathbf{f}($ MPR $)$
3b. $\quad$ LAd $_{\text {P-SAP }}=\mathbf{f}(\mathrm{MPR})$
4a. $\quad \operatorname{CrP}_{\mathrm{SAP}}=\mathbf{f}(\mathrm{MPR})$
4b. $\quad \mathrm{CrP}_{\mathrm{p}-\mathrm{SAP}}=\mathbf{f}(\mathrm{MPR})$

Where

$\mathrm{TAV}_{\mathrm{SAP}}=$ Total Asset Value of Commercial Banks during the SAP period. This is the Dependent Variable.

$\mathrm{TAV}_{\mathrm{P}-\mathrm{SAP}}=$ Total Asset Value of Commercial Banks during the P-SAP period. This is the Dependent Variable. $\mathrm{DpM}_{\mathrm{SAP}}=$ Deposit Mobilization during the SAP period

$\mathrm{DpM}_{\mathrm{P}-\mathrm{SAP}}=$ Deposit Mobilization during the Post SAP period

$\mathrm{CrP}_{\mathrm{SAP}}=$ Credit to the Private Sector during the SAP period

$\mathrm{CrP}_{\mathrm{p}-\mathrm{SAP}}=$ Credit to the Private Sector during the Post SAP period

$\mathrm{SAP}=$ Structural Adjustment Programme.

$\mathrm{P}-\mathrm{SAP}=$ Post SAP period.

MPR=Monetary Policy Rate is the independent variable which measures the rediscount rate (interest rate) of the Central Bank

\subsubsection{Analytical Model}

The study employed a regression model to determine the relative significance of each of the variable identified above. Coefficient of correlation $(\mathrm{R})$ was used to determine the strength of the relationship between the dependent and independent variables. The model took the following format;

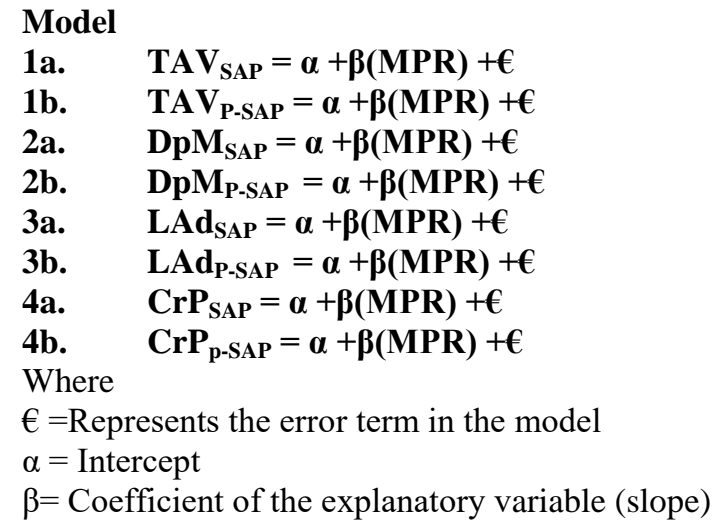

\subsection{Nature and Sources of Data}

Secondary data was used. Data was obtained from published materials such as the statistical Bulletins of the Central Bank of Nigeria the internet.

\subsection{Technique of Analysis and Presentation}

Data obtained from secondary data was analyzed using Statistical Package for Social Sciences (SPSS) and Microsoft Excel Package. The regression and correlation analysis was used as the analysis technique. The results obtained from the model are represented in tables to aid in analysis and ease with which the inferential statistics was drawn. The choice of these techniques was inspired by the work of Udeh (2015) and Enyioko (2012) who both used regression and correlation techniques.

\subsection{Problems and Limitation of the Study}

The conduct of research in Nigeria and of course most developing countries is filled with challenges. However in this particular research, the following challenges may arise;

a. the challenge of generalizing findings of this study to all the Commercial Banks in Nigeria

b. the cost of conducting a thorough study as this was really challenging. 


\subsection{Introduction}

\section{Data Analysis, Results And Interpretations}

This chapter presents the data analysis, interpretation and discussion of the research findings. The collected data was analyzed and interpreted in line with the study which is to determine the effect of Monetary Policy (interest) Rate on the financial performance of Commercial Banks in Nigeria.

\subsection{Summary of Statistics}

Descriptive and inferential statistics was employed. Also, regression and correlation analysis was used to determine the relationship between Monetary Policy Interest Rates and financial performance of the Commercial Banks in Nigeria (represented by Total Assets, Deposit Mobilization, Credit to the Private Sector and Loans and Advances). The period was distinguished into the SAP period and the Post SAP period.

\section{Research Question 1a: Did Monetary Policy Interest Rate have any significant impact on financial} performance of Commercial Banks during the SAP period.

Table 1a. Showing the Regression Analysis between Monetary Policy Interest Rate and Total Asset Value of Commercial Banks during the SAP period (1986-1999)

Coefficients $^{\mathrm{a}}$

\begin{tabular}{|c|c|c|c|c|c|c|}
\hline \multirow{2}{*}{\multicolumn{2}{|c|}{ Model }} & \multicolumn{2}{|c|}{ Unstandardized Coefficients } & \multirow{2}{*}{\begin{tabular}{c|} 
Standardized Coefficients \\
Beta
\end{tabular}} & \multirow[b]{2}{*}{$\mathrm{T}$} & \multirow[b]{2}{*}{ Sig. } \\
\hline & & B & Std. Error & & & \\
\hline \multirow[t]{2}{*}{1} & (Constant) & 232.346 & 355.541 & & .653 & .526 \\
\hline & MONETARY POLICY RATE (\%) & 4.766 & 22.296 & .062 & .214 & .834 \\
\hline
\end{tabular}

a. Dependent Variable: TOTAL ASSET VALUE (^'b)

\section{Source: Research Findings}

The model developed from the coefficient in Table 1 is;

$\mathrm{TAV}_{\text {sap }}=\mathrm{f}(\mathrm{MPR})$

Therefore the regression Model

$\mathrm{TAV}_{\mathrm{sap}}=\alpha+\beta(\mathrm{MPR})+€$

Therefore;

$\mathrm{TAV}_{\text {sap }}=232.346+4.766(\mathrm{MPR})$

This model explains that MPR has a positive coefficient (4.766) and therefore an increase in MPR would likely lead to an increase in Total Asset Value. It explains that an increase in 1percent MPR would likely increase Total Asset Value by 4.766 (Billion Naira). However, the relationship shows a weak (not significant) correlation of 0.062 or $6.20 \%$. The relationship is also not significant at a $5 \%$ and $10 \%$ probability level as evidenced by the student $t$ test. Also P-Value $(0.834)>0.05$ shows the relationship is not significant at a $5 \%$ probability level. Therefore, from our analysis, we conclude that MPR during the SAP Period had no significant impact on banking performance in Nigeria.

Research Question 1b. Did Monetary Policy Interest Rate have any significant impact on financial performance of Commercial Banks during the P-SAP period.

Table 1b. Showing the Regression Analysis between Monetary Policy and Total Asset Value of Commercial Banks for the Post SAP Period (2000-2013)

\section{Coefficients $^{\mathrm{a}}$}

\begin{tabular}{|c|c|c|c|c|c|}
\hline \multirow[b]{2}{*}{ Model } & \multicolumn{2}{|c|}{ Unstandardized Coefficients } & \multirow{2}{*}{$\begin{array}{c}\begin{array}{c}\text { Standardized } \\
\text { Coefficients }\end{array} \\
\text { Beta }\end{array}$} & \multirow[b]{2}{*}{$\mathrm{T}$} & \multirow[b]{2}{*}{ Sig. } \\
\hline & B & Std. Error & & & \\
\hline $1 \quad$ (Constant) & 30.128 & 6.188 & & 4.869 & .000 \\
\hline MONETARY POLICY RATE & -1.644 & .493 & -.679 & -3.332 & .005 \\
\hline
\end{tabular}

a. Dependent Variable: TOTAL ASSET VALUE (P-SAP) (N'tr)

The model developed from the coefficient in Table 2 is;

$\mathrm{TAV}_{\text {P-sap }}=\mathrm{f}(\mathrm{MPR})$

Therefore the regression Model

$\mathrm{TAV}_{\mathrm{p}-\mathrm{sap}}=\alpha+\beta(\mathrm{MPR})+€$

Therefore;

$\mathrm{TAV}_{\text {p-sap }}=30.128-1.644$ (MPR) 
This model explains that MPR has a negative coefficient (-1.644) and therefore an increase in MPR would likely lead to a decrease in Total Asset Value. It explains that an increase in 1percent MPR would likely decrease Total Asset Value by 1.644 (Trillion Naira)

The relationship shows a strong, significant correlation of 0.679 or $67.9 \%$. Also P-Value $(0.005)<0.05$ shows the relationship is also significant at a $5 \%$ and $1 \%$ probability level. Therefore, from our analysis, we conclude that MPR during the Post SAP Period had a significant impact on banking performance in Nigeria.

Research Question 2a. Did Monetary Policy Interest Rate have any significant impact on Deposit Mobilization of Commercial Banks during the SAP period.

Table 2a. Showing the Regression Analysis between Monetary Policy Interest Rate and Deposit Mobilization of Commercial Banks for the SAP Period (1986-1999)

Coefficients $^{\mathrm{a}}$

\begin{tabular}{|c|c|c|c|c|c|c|}
\hline \multirow{2}{*}{\multicolumn{2}{|c|}{ Model }} & \multicolumn{2}{|c|}{ Unstandardized Coefficients } & \multirow{2}{*}{$\frac{\text { Standardized Coefficients }}{\text { Beta }}$} & \multirow[b]{2}{*}{$\mathrm{t}$} & \multirow[b]{2}{*}{ Sig. } \\
\hline & & B & Std. Error & & & \\
\hline 1 & (Constant) & 106.787 & 159.573 & & 669 & .516 \\
\hline & MONETARY POLICY RATE (\%) & 2.194 & 10.007 & .063 & .219 & .830 \\
\hline
\end{tabular}

a. Dependent Variable: DEPOSIT MOBILIZATION (^'b)

The model developed from the coefficient in Table $1 \mathrm{~b}$ is;

$\mathbf{D p M}_{\text {SAP }}=\mathrm{f}(\mathrm{MPR})$

Therefore the regression Model

$\operatorname{DpM}_{\mathrm{SAP}}=\boldsymbol{\alpha}+\boldsymbol{\beta}(\mathrm{MPR})+€$

Therefore;

DpM $_{\text {SAP }}=106.787+2.194($ MPR)

This model explains that MPR has a positive coefficient $(+2.194)$ and therefore an increase in MPR would likely lead to an increase in Deposit Mobilization. It explains that an increase in 1percent MPR would likely increase Deposit Mobilization by 2.194 (Billion Naira)

The relationship shows a weak correlation of 0.063 or $6.3 \%$. Also P-Value $(0.830)>0.05$ shows the relationship is not significant at a $5 \%$ and $10 \%$ probability level.

Therefore, from our analysis, we conclude that MPR during the SAP Period had no significant impact on Deposit Mobilization in Nigeria.

Research Question 2b. Did Monetary Policy Interest Rate have any significant impact on Deposit Mobilization of Commercial Banks during the P-SAP period.

Table 2b. Showing the Regression Analysis between Monetary Policy and Deposit Mobilization of Commercial Banks for the Post SAP Period (2000-2013)

Coefficients $^{\mathrm{a}}$

\begin{tabular}{|c|c|c|c|c|c|c|}
\hline \multirow[b]{2}{*}{ Model } & & \multicolumn{2}{|c|}{ Unstandardized Coefficients } & \multirow{2}{*}{$\begin{array}{c}\begin{array}{c}\text { Standardized } \\
\text { Coefficients }\end{array} \\
\text { Beta }\end{array}$} & \multirow[b]{2}{*}{$\mathrm{T}$} & \multirow[b]{2}{*}{ Sig. } \\
\hline & & B & Std. Error & & & \\
\hline 1 & (Constant) & 16490.014 & 3876.270 & & 4.254 & .001 \\
\hline & MONETARY POLICY RATE P & -889.342 & 310.753 & -.637 & -2.862 & 014 \\
\hline
\end{tabular}

a. Dependent Variable: DEPOSIT MOBILIZATION (^'b)

Source: Research Findings

The model developed from the coefficient in Table $2 b$ is;

DpM $_{\text {P-SAP }}=\mathrm{f}(\mathrm{MPR})$

Therefore the regression Model

$\operatorname{DpM}_{\text {P-SAP }}=\alpha+\beta(M P R)+€$

Therefore;

DpM $_{\text {P-SAP }}=16490.014-889.342$ (MPR)

This model explains that MPR has a negative coefficient (- 889.342) and therefore an increase in MPR would likely lead to a decrease in Deposit Mobilization. It explains that an increase in 1percent MPR would likely decrease Deposit Mobilization by 889.342 (Billion Naira). The relationship shows a strong correlation of 0.637 or $63.7 \%$. Also P-Value $(0 . .014)>0.05$ shows the relationship is significant at a $5 \%$ and $1 \%$ probability level. Therefore, from our analysis, we conclude that MPR during the Post SAP Period had a significant impact on Deposit Mobilization in Nigeria. 
Research Question 3a. Did Monetary Policy Interest Rate have any significant impact on Loans and Advances of Commercial Banks in Nigeria during the SAP period.

Table 3a. Showing the Regression Analysis between Monetary Policy Interest Rate and Loans and Advances of Commercial Banks in Nigeria for the SAP Period (1986-1999)

Coefficients ${ }^{\mathrm{a}}$

\begin{tabular}{|c|c|c|c|c|c|c|}
\hline \multirow{2}{*}{\multicolumn{2}{|c|}{ Model }} & \multicolumn{2}{|c|}{ Unstandardized Coefficients } & \multirow{2}{*}{$\begin{array}{c}\begin{array}{c}\text { Standardized } \\
\text { Coefficients }\end{array} \\
\text { Beta }\end{array}$} & \multirow[b]{2}{*}{$\mathrm{t}$} & \multirow[b]{2}{*}{ Sig. } \\
\hline & & B & Std. Error & & & \\
\hline \multirow[t]{2}{*}{1} & (Constant) & 139.095 & 146.148 & & .952 & .360 \\
\hline & MONETARY POLICY RATE (\%) & -1.602 & 9.165 & -.050 & -.175 & .864 \\
\hline
\end{tabular}

The model developed from the coefficient in Table 3a is;

$\mathbf{L A d}_{\text {SAP }}=\mathrm{f}(\mathrm{MPR})$

Therefore the regression Model

LAd $_{\mathrm{SAP}}=\boldsymbol{\alpha}+\boldsymbol{\beta}(\mathrm{MPR})+€$

Therefore;

$\mathbf{L A d}_{\mathbf{S A P}}=139.095-1.602(\mathrm{MPR})$

This model explains that MPR has a negative coefficient (-1.602) and therefore an increase in MPR would likely lead to a decrease in Loans and Advance. It explains that an increase in 1percent MPR would likely decrease Loans and Advance by 1.602 (Billion Naira). However,

the relationship shows a weak correlation of 0.05 or 5.0 percent $(\%)$. Also P-Value $(0.864)>0.05$ shows the relationship is not significant at a 5\% probability level. Therefore, from our analysis, we conclude that MPR during the SAP Period had no significant impact on Loans and Advance of Commercial Banks in Nigeria.

Research Question 3b: Did Monetary Policy Interest Rate have any significant impact on Loans and Advances of Commercial Banks in Nigeria during the P-SAP period.

Table 3b. Showing the Regression Analysis between Monetary Policy Interest Rate and Loans and Advances of Commercial Banks in Nigeria during the P-SAP Period (2000-2013)

Coefficients $^{\mathrm{a}}$

\begin{tabular}{|c|c|c|c|c|c|c|}
\hline \multirow{2}{*}{\multicolumn{2}{|c|}{ Model }} & \multicolumn{2}{|c|}{ Unstandardized Coefficients } & \multirow{2}{*}{$\begin{array}{c}\begin{array}{c}\text { Standardized } \\
\text { Coefficients }\end{array} \\
\text { Beta } \\
\end{array}$} & \multirow[b]{2}{*}{$\mathrm{T}$} & \multirow[b]{2}{*}{ Sig. } \\
\hline & & B & Std. Error & & & \\
\hline 1 & (Constant) & 13542.636 & 2484.501 & & 5.451 & .000 \\
\hline & MONETARY POLICY RATE P & -745.898 & 199.178 & -.734 & -3.745 & .003 \\
\hline
\end{tabular}

a. Dependent Variable: LOANS AND ADVANCES (^'b)

Source: Research Findings

The model developed from the coefficient in Table $3 \mathrm{a}$ is;

LAd $_{\text {P-SAP }}=\mathrm{f}(\mathrm{MPR})$

Therefore the regression Model

LAd $_{\text {P-SAP }}=\alpha+\beta(M P R)+€$

Therefore;

LAd $_{\text {P-SAP }}=13542.636-745.898(\mathrm{MPR})$

This model explains that MPR has a negative coefficient (-745.898) and therefore an increase in MPR would likely lead to a decrease in Loans and Advance. It explains that an increase in 1percent MPR would likely decrease Loans and Advance by 745.898 (Billion Naira). The relationship shows a very strong (significant) correlation of 0.734 or 73.4 percent. Also P-Value $(0.003)<0.05$ shows the relationship is significant at a $5 \%$ and $1 \%$ probability level. Therefore, from our analysis, we conclude that MPR during the P-SAP Period had significant impact on Loans and Advance of Commercial Banks in Nigeria. 
Research Question 4a. Did Monetary Policy Interest Rate have any significant impact on Commercial Banks' Credit to the Private Sector in Nigeria during the SAP period.

Table 4a. Showing the Regression Analysis between Monetary Policy Interest Rate and Commercial Banks' Credit to the Private Sector in Nigeria during the SAP Period (1986-1999)

Coefficients $^{\mathrm{a}}$

\begin{tabular}{|ll|r|r|r|r|r|}
\hline \multirow{2}{*}{ Model } & & \multicolumn{2}{|c|}{ Unstandardized Coefficients } & Standardized Coefficients & & \\
\cline { 3 - 6 } & & \multicolumn{1}{c|}{ B } & Std. Error & Beta & \multicolumn{1}{c|}{ Sig. } \\
\hline & (Constant) & 410712.585 & 196843.041 & & 2.086 & .082 \\
& MONETARY POLICY RATE (\%) & -10746.522 & 11763.553 & -.349 & -.914 & .396 \\
\hline
\end{tabular}

a. Dependent Variable: CREDIT TO THE PRIVATE SECTOR (N'm)

The model developed from the coefficient in Table 3a is;

$\mathrm{CrP}_{\text {SAP }}=\mathrm{f}(\mathrm{MPR})$

Therefore the regression Model

$\operatorname{CrP}_{\text {SAP }}=\alpha+\beta(M P R)+€$

Therefore;

$\mathbf{C r P}_{\mathrm{SAP}}=410712.585-10746.522(\mathrm{MPR})$

This model explains that MPR has a negative coefficient (-10746.522) and therefore an increase in MPR would likely lead to a decrease in Credit to the Private Sector. It explains that an increase in 1percent MPR would likely decrease Credit to the Private Sector by 10746.522 (Million Naira). However, the relationship shows a negative and weak correlation of 0.349 or 34.9 percent. Also P-Value $(0.396)>0.05$ shows the relationship is not significant at a $5 \%$ probability level.

Therefore, from our analysis, we conclude that MPR had no significant impact on Commercial Banks' Credit to the Private Sector in Nigeria during the SAP Period.

Research Question 4b. Did Monetary Policy Interest Rate have any significant impact on Commercial Banks' Credit to the Private Sector in Nigeria during the P-SAP period.

Table 4b. Showing the Regression Analysis between Monetary Policy Interest Rate and Commercial Banks' Credit to the Private Sector in Nigeria during the P-SAP Period (2000-2013)

Coefficients $^{\mathrm{a}}$

\begin{tabular}{|c|c|c|c|c|c|c|}
\hline \multirow{2}{*}{\multicolumn{2}{|c|}{ Model }} & \multicolumn{2}{|c|}{ Unstandardized Coefficients } & $\begin{array}{l}\text { Standardized } \\
\text { Coefficients }\end{array}$ & \multirow[b]{2}{*}{$\mathrm{t}$} & \multirow[b]{2}{*}{ Sig. } \\
\hline & & B & Std. Error & Beta & & \\
\hline \multirow[t]{2}{*}{1} & (Constant) & 15561.541 & 3087.421 & & 5.040 & .000 \\
\hline & MONETARY POLICY RATE & -862.572 & 247.513 & -.709 & -3.485 & .005 \\
\hline
\end{tabular}

a. Dependent Variable: CREDIT TO PRIVATE SECTOR (N'b)

The model developed from the coefficient in Table $4 \mathrm{~b}$ is;

CrPP-SAP $_{\text {f }}$ (MPR)

Therefore the regression Model

$\mathrm{CrP}_{\mathrm{P}-\mathrm{SAP}}=\boldsymbol{\alpha}+\boldsymbol{\beta}(\mathrm{MPR})+\boldsymbol{\epsilon}$

Therefore;

$\mathbf{C r P}_{\mathbf{P}-\mathrm{SAP}}=15561.541-862.572(\mathrm{MPR})$

This model explains that MPR has a negative coefficient (-862.572) and therefore an increase in MPR would likely lead to a decrease in Credit to the Private Sector. It explains that an increase in 1percent MPR would likely decrease Credit to the Private Sector by 862.572 (Billion Naira). However, the relationship shows a negative and strong (significant) correlation of -0.709 or 70.9 percent. Also P-Value $(0.005)<0.05$ shows the relationship is significant at a $5 \%$ probability level.

Therefore, from our analysis, we conclude that MPR had a significant impact on Commercial Banks' Credit to the Private Sector in Nigeria during the SAP Period.

\subsection{Discussion and Interpretation of Result}

The study sought to determine the impact of monetary policy regimes on bank performances during the SAP and Post SAP era. The study found;

1. That MPR had no significant impact on banking performance in Nigeria during the SAP Period. 
2. That MPR had no significant impact on Deposit Mobilization in Nigeria during the SAP Period.

3. That MPR had no significant impact on Loans and Advance of Commercial Banks in Nigeria during the SAP Period.

4. That MPR had no significant impact on Commercial Banks' Credit to the Private Sector in Nigeria during the SAP Period.

This findings of this study (No. 1-4) agrees with Udeh (2015) who found that a good number of monetary policy instruments do not impact significantly on profitability of Commercial Banks in Nigeria. It also agreed with Enyioko (2012) that interest rate policies have not improved the overall performances of the banks significantly.

The study however found;

5. That MPR during the Post SAP Period had a significant impact on banking performance in Nigeria.

6. That MPR during the Post SAP Period had a significant impact on Deposit Mobilization in Nigeria.

7. That MPR during the P-SAP Period had significant impact on Loans and Advance of Commercial Banks in Nigeria

8. That MPR had a significant impact on Commercial Banks' Credit to the Private Sector in Nigeria during the SAP Period.

The findings of this study (No. 5-8) agrees with Okoye and Eze (2013) who found out that lending rate and Monetary Policy rate have significant and positive effects on the performance of Nigeria Deposit Money Banks. It was discovered that banking performance during SAP period was not significantly impacted by the Monetary Policy Interest Rate while banking performance during P-SAP period was significantly impacted by the Monetary Policy Interest Rate. This was consistent for all the variables considered. This included the Total Assets Value, Deposit Mobilization, Loans and Advances and Credit to the Private Sector respectively.

\section{$5.1 \quad$ Introduction}

\section{Summary, Conclusion and Recommendation}

This chapter presents the summary of findings, conclusion and recommendation of the study. It also highlights the limitation that were encountered in the study with suggestions for further research

\subsection{Summary}

The study sought to investigate the effect of Monetary Policy Regimes on the financial performance of Commercial Banks in Nigeria. Descriptive and Ex-post facto Research Design was used to carry out the objective of the study. The research used regression and correlation analysis technique to identify the relationship between Monetary Policy Interest Rate and Total Assets Value, Deposit Mobilization, Loans and Advances and Credit to the Private Sector respectively. Monetary Policy Rate was the independent variable while Total Assets Value, Deposit Mobilization, Loans and Advances and Credit to the Private Sector were the dependent variable in different regression equations.

\subsection{Conclusion}

From the findings the study concludes that;

1. That MPR had no significant impact on Total Asset Value of Commercial banks in Nigeria during the SAP Period but had a significant impact on Total Asset Value of Commercial banks in Nigeria during the Post SAP Period .

2. That MPR had no significant impact on Deposit Mobilization in Nigeria during the SAP Period but had a significant impact on Deposit Mobilization in Nigeria during the Post SAP Period.

3. That MPR had no significant impact on Loans and Advance of Commercial Banks in Nigeria during the SAP Period but had a significant impact on Loans and Advance of Commercial Banks in Nigeria during the Post SAP Period.

4. That MPR had no significant impact on Commercial Banks' Credit to the Private Sector in Nigeria during the SAP Period but had a significant impact on Commercial Banks' Credit to the Private Sector in Nigeria during the Post SAP Period.

5. That MPR during the SAP Period had no significant impact on banking performance in Nigeria but had a significant impact on banking performance in Nigeria during the Post SAP period. This result may have arisen because of the political interference in the banking industry during the SAP period.

\subsection{Policy Recommendation}

Based on the findings of the study the following recommendations are put forward. First, that Monetary Policy Rate as a policy instrument alone may not be effective in generating and simulating the level of economic activity desired in the banking industry. Also, policy makers should administer the Monetary Policy Instruments 
Impact of Monetary Policy (Interest Rate) Regimes on the Performance of the Banking Sector ..

to ensure they are effective in generating and invigorating the level of economic activity desired in the banking industry. Also political interference in the banking system is inimical to the growth and health of the industry, therefore it should be minimized.

\subsection{Suggestions for further research}

The study still has a wide gap to be filled. Other determinants of Performance could be tested and other analytical tools could be used. Further study can be done in the area of;

1. The Impact of Monetary Policy Regimes on the profitability Microfinance banks in Nigeria.

2. The Impact of Monetary Policy Regimes on Economic Growth in Nigeria.

\section{APPENDICES}

TABLE 5: Showing The Monetary Policy Interest Rate, Credit To The Private Sector, Total Assets Of Commercial Banks, Deposit Mobilization And Loans And Advances Of The Commercial Banks For The Sap Period 1986-1999

\begin{tabular}{|c|c|c|c|c|c|}
\hline DATE & $\operatorname{MPR}(\%)$ & TAV (N'billion) & DPM(N'billion) & CRP(N'Million) & L\&A(N'billion) \\
\hline 1986 & 10.00 & 39.68 & 18.1 & & 15.7 \\
\hline 1987 & 12.75 & 49.83 & 23.1 & & 17.5 \\
\hline 1988 & 12.75 & 58.03 & 29.1 & & 19.6 \\
\hline 1989 & 18.50 & 64.87 & 27.2 & & 22 \\
\hline 1990 & 18.50 & 82.96 & 38.8 & & 26 \\
\hline 1991 & 14.50 & 117.51 & 52.4 & & 31.3 \\
\hline 1992 & 17.50 & 159.19 & 75.1 & 72456.3 & 42.7 \\
\hline 1993 & 26.00 & 226.16 & 110.4 & 88821 & 65.7 \\
\hline 1994 & 13.50 & 295.03 & 142.5 & 143516.8 & 94.2 \\
\hline 1995 & 13.50 & 385.14 & 179 & 204090.6 & 114.6 \\
\hline 1996 & 13.50 & 458.78 & 214.4 & 254853.1 & 169.4 \\
\hline 1997 & 13.50 & 584.38 & 269.9 & 311358.4 & 385.6 \\
\hline 1998 & 14.31 & 694.62 & 314.4 & 366544.1 & 272.9 \\
\hline 1999 & 18.00 & 1070.02 & 476.4 & 449054.3 & 322.8 \\
\hline \multicolumn{6}{|c|}{ Source: CBN STATISTICAL BULLETIN 2013} \\
\hline \multicolumn{6}{|c|}{ NOTES } \\
\hline CRP & \multicolumn{5}{|c|}{ Commercial Banks Total Credit to Private Sector (in Million Naira) } \\
\hline \multicolumn{6}{|c|}{ DPM Deposit Mobilization of Commercial Banks (Demand Deposits +Time, Savings \& Foreign Currency Deposits)(in Billion Nai } \\
\hline TAV & \multicolumn{5}{|c|}{ Total Assets of Commercial Banks (in Billion Naira) } \\
\hline MPR & \multicolumn{5}{|c|}{ Monetary Policy Rate Of Central Bank of Nigeria (in percent) } \\
\hline L\&A & \multicolumn{5}{|c|}{ Sectorial Distribution of Commercial Banks' Loans and Advances1 (in Billion Naira) } \\
\hline
\end{tabular}

Table 6: Showing The Monetary Policy Interest Rate, Credit To The Private Sector, Total Assets Of Commercial Banks, Deposit Mobilization And Loans And Advances Of The Commercial Banks For The Post Sap Period 2000-2013

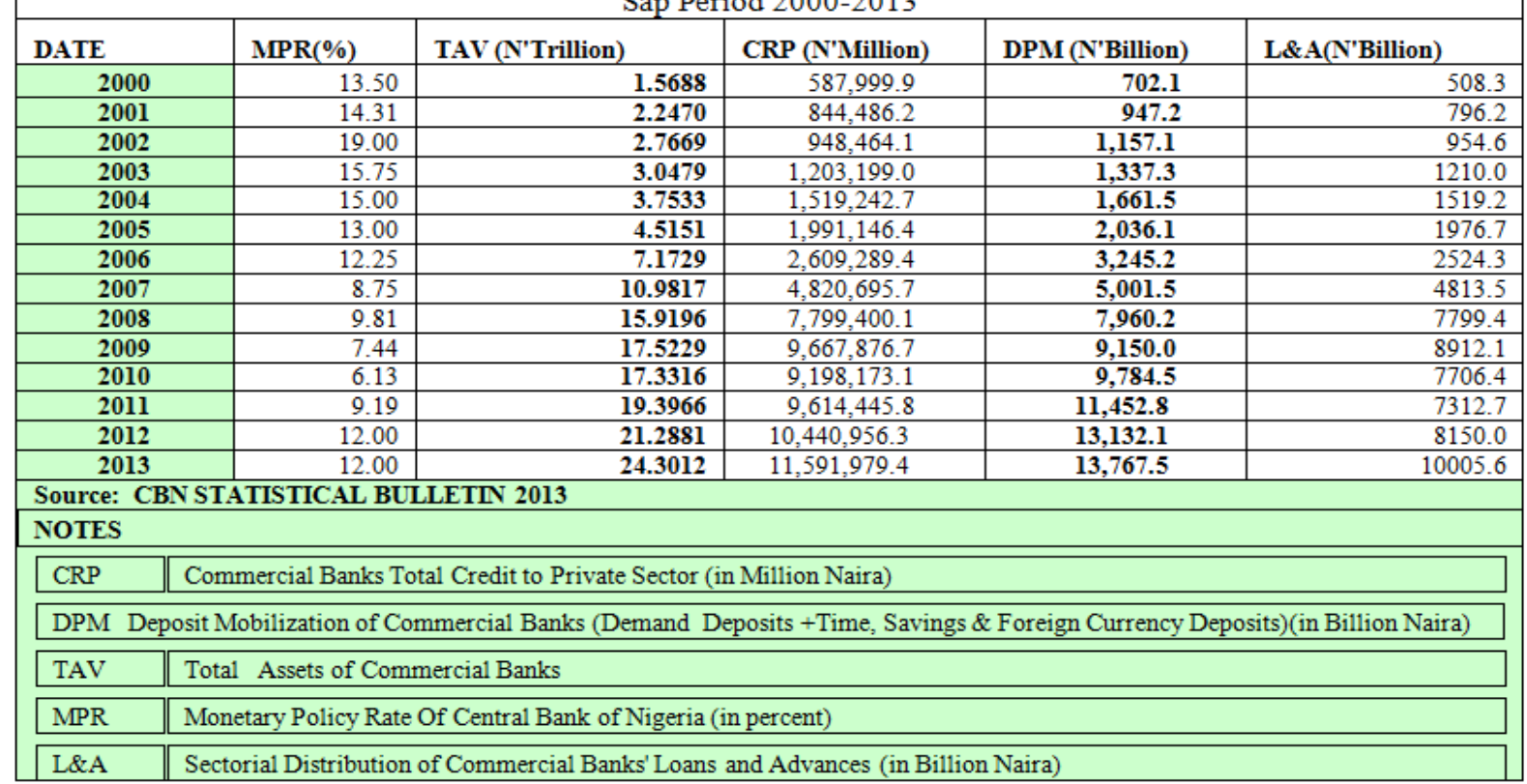




\section{Bibliography}

[1]. Aburime, T.U. (2008). Determinants of Bank Profitability: Macroeconomic Evidence from Nigeria. Lagos Journal of Banking and Finance and Economics. (http://ssrn.com/abstract=1231064)

[2]. Adebiyi M.A. and Babatope O.B. (2004). International Framework, Interest Rate Policy and the financing of the Nigerian Manufacturing Subsector. A paper presented at the African Development and Poverty Reduction (the Macro Linkage) Conference at Lord Charles Hotel Somerset West, S.A. Oct 13-15.

[3]. Ahmad, H. I.(2003). Trends in Profitability of Banks in Nigeria Before and During Interest Rate Regulation, Nigerian Deposit Insurance Corporation Quarterly Report, Vol 13(3) Sept., pp 59-82.

[4]. Al-Tamini, H. and Hassan, A. (2010). Factors Influencing Performance of the UAE Islamic and Conventional National Banks. Department of Accounting and Finance and Economics, College of Business Administration, University of Sharjah.

[5]. Bekaert G. (1998). Regime Switches in Interest Rates. Cambridge, Mass National Bureau of Economic Research

[6]. Caplan, B. (2000). Rational Expectation. George Mason University, Department of Economics.

[7]. Carletti, E.,Cerasi,V. and Daltung, S. (2006). Multiple Bank Lending: Diversification and Freeriding in Monitoring, Working Paper, Department of Statistics: Universitadegli studi Milano Bicocca, International Journal of Financial Research 2(2):34-54

[8]. CBN (2013). Central Bank of Nigeria Statistical Bulletin

[9]. Chen M. (2011). Interest Rate Spread. Washington D.C. International Monetary Fund, Monetary and Capital Market Dept.

[10]. Chodechai, S. (2004). Determinants of Bank Lending in Thailand. An Empirical Examination for the years 1992-1996, Unpublished Thesis.

[11]. Cooper, R., and Schinder, S., (2008). Business Research Methods. 10th Ed. New York: Mc Graw Hill.

[12]. Corbitt (2012). Interest Rate Swaps and other Derivatives. New York. Columbia Business School.

[13]. Damilola, D. A. (2007). Corporate Finance: Issues, Investigations, Innovations and Applications, 2ed, Lagos, High Rise Publications.

[14]. Deloof, M. (2003). Does Working Capital Management Affect Profitability of Belgian Firms? Journal of Business Finance and Accounting, Vol. 30, No. $3 \& 4$.

[15]. Degryse H., Maschelein, N. and Mitchell, J. (2004). SME's and Bank Lending Relationships, the impact of Mergers. National Bank of BelgiumWorking Paper.No. 46.

[16]. Emmanuelle, J. (2003). Monetary and Fiscal policy. Kenya University of Nairobi.

[17]. Enyioko, N. (2012). Impact of Interest Rate Policy and Performance of Deposit Money banks in Nigeria. Global Journal of Management and Business Research. Vol 12(21). ISSN Online: 2249-4588, ISSN Print: 0975-5853.

[18]. Ewert, R., Szczesmy, A. and Schenk, G. (2000). Determinants of Bank Lending Performance in Germany . Schmalenbach Business Review (SBR), 52, 344-362

[19]. Felicia, O.O. (2011). Determinants of Commercial Banks' Lending Behaviour in Nigeria. International Journal of Financial Research. Vol 2(2). www.sciedu.ca/ijfr

[20]. Friedman, B.M. and Kutnner, K.N. (1991). Why does the Paper Bill Spread Predict Real Economic Activity? Cambridge, M.A., National Bureau of Economic Research.

[21]. Gavin, A. (2010). High Yields on German Interest Rates. Cambridge, M.A. National Bureau of Economic Research.

[22]. Gertler, M. and Gilchrist, S. (1994). The Role of Credit Market Imperfections in the Monetary Transmission Mechanism: Arguments and Evidence. Scandinavian Journal of Economics, Vol 95, No. 1.

[23]. Godlewski, C.J. and Zaine, Y. (2008). How many Banks does it Take to lend? Empirical Evidence from Europe, Working Paper. World Bank Series.

[24]. Gilchris, M. (2013). Influence of Bank Specific and Macroeconomic Factors on the Profitability of 25 Commercial Banks in Pakistan during the Time Period 2007-2011. American Journal of Business and Finance.

[25]. Giovanni, J. and Shambaugh J.C. (2006). The Impact of Foreign Interest rates on the Economy: The Role of the Exchange Rate Regime. Cambridge, National Bureau of Economic Research.

[26]. Hara M. (1983). A dynamic Theory of the Banking Firm. The Journal of Finance. Vol 38, 127-140

[27]. Hayes, K.C. (1992). How Fiscal Policy and interest Rates Impact Banks' Bottom Lines: A look at History. Value Walk: http://www.valuewalk.com/2013/06interest rates banks earnings good/. Retrieved April 15, 2016.

[28]. Hayes, K.C. (2013). How Interest Rates Impact Banks' Bottom Lines: A look at History. Value Walk: http://www.valuewalk.com/2013/06interest rates banks earnings good/. Retrieved April 15, 2016.

[29]. Hualan, C. (1992). Fiscal Policy and Interest Rates, How Sustainable is the New Economy? Washington D.C.: International Monetary Fund, IMF Institute.

[30]. International Monetary Fund, (2001). Regional Economic Outlook: Sub-Saharan Africa. World Economic and Financial Surveys. IMF Working Papers, 0258-7440.60.

[31]. International Monetary Fund, (2016). World Bank: Retrieved May 5, 2016. http://data.worldbank.org/indicator/FD.AST.PRVT.GD.ZS

[32]. Irungu, P.N. (2013). The Effect of Interest Rate Spread on Financial Performance of Commercial Banks in Kenya. An Msc Research Project submitted to the University of Nairobi.

[33]. Karceski J., Ongena, S. and Smith, D.C. (2004). The impact of Bank Consolidation on Commercial Borrower Welfare. Journal of Finance 60(4): 2043-2082.

[34]. Karl, E., Ray C. and Shannon, M. (2009). Principles of Economics. Pearson International Edition. Pretence Hall.

[35]. Kashyap, A. K. and Stein, J. C. (1995). The Impact of Monetary Policy on Bank Balance Sheets. Carnegie Rochester Conference Series on Public Policy, Pp 42:151-195.

[36]. Keynes (2006). The General Theory of Employment, Interest and Money. New York: Atlantic Publishers and Distributors; Original Published 1936

[37]. Kiarie, J. (2011). Best Measure on Assets. Kenya: University of Nairobi

[38]. KPMG, (2005). Working Capital Management Survey: How European Companies manage their Working Capital. KPMG International. Retrieved on 15/03/2016 from http://www.ch/library/pdf/kpmg survey _ Working Capital Management_e.pdf

[39]. Kothari, C. R. (2008). Research Methodology: Methods and Techniques. New Delhi: New Age International Publishers, ISBN: 978-81-224-3623-5, 3rd Edition

[40]. Lazaridis, I. and Tryfonidis, D. (2005). The relationship between Working Capital Management and Profitability of Listed companies in the Athens Stock Exchange. Retrieved on 15/04/2016 from http://papers.ssrn.com/sol13/papers.cfm?abstract id 931591.

[41]. Mlachila, M. (2002). Interest Rate Spread. Washington D.C. International Monetary Fund, Monetary and Capital Market Dept. 
[42]. Mugenda, A., \& Mugenda, O., (2003). Research Methods; Quantitative and Qualitative Approaches. Africa Center for Technology (ACTS), Nairobi Kenya

[43]. Ngugi, R. (2000). Banking Sector Interest Rate Spread in Kenya. Nairobi, Kenya Institute for Public Policy Research and Analysis.

[44]. Ngugi , R. (2004). Determinants of Interest Rates Spread In Kenya, Nairobi. Kenya Institute for Public Policy Research and Analysis.

[45]. Ngugi , R. and Kabubo, J. (1998). Financial Sector Reforms and Interest in Kenya: Kenya Institute for Policy Research and Analysis.

[46]. Ngure I.M. (2014). The effect of Interest Rates on Financial Performance of Commercial Banks in Kenya. An Msc. Research Project Submitted to the Department of Businees Admin., University of Nairobi.

[47]. Nwakanma, F.C. and Ifeanyi, M. (2013). Influence of Interest Rates Regimes on Deposit Money Banks' Credit in Nigeria. An Econometric Assessment.

[48]. Nwude, E. C., (2013). The Profitability of Nigerian Banks, Asian Journal of Empirical Research. 7-3(8)-AJER-1005-1019. (http://aessweb.com/journal-detail.php?id=5004)

[49]. Ogunlewe, R.W. (2001). Sensitivity of Bank Stock Returns to Market and Interest Rate Risks: An Empirical Investigation, Nigerian Deposit Insurance Corporation Quarterly Review, Vol. 11( 1-2), March/June: pp 57-77.

[50]. Okafor, F. O. (2011). 50 years of Banking Sector Reforms in Nigeria(1960-2010): Past lessons: Future Imperatives, Enugu, Ezu Books ltd

[51]. Okoye, V. and Eze, R.O. (2013). Effect of bank lending rate on the performance of Nigerian deposit money banks, International Journal of Business and Management Review, Vol. 1, No. 1, March 2013, pp.34-43.

[52]. Ongena, S. and Smith D.C. (2000). What determines the number of bank relationships: Cross Country Evidence. Journal of Financial Intermediation, 9(5):26-56

[53]. Ongore, V. (2013). Determinants of Financial Performance of Commercial Banks in Kenya. International Journal of Economics and Financial Issues, ISSN: 2146-4138

[54]. Pandey, I. M. (2005). Financial Management, 9ed, New Delhi, Vikas

[55]. Papa, V. (2014). The Great Unwind: What will Rising Interest Rates Mean for Banks Risk Exposures? Market Integrity Insights.

[56]. Punita, R. and Somaiya, K.J. (2006). Monetary Policy: It's Impact on the Profitability of Banks in India. Intermediate Business and Economics Research Journal, Vol. 5(3): pp. 15-19.

[57]. Raheman, A. and Nasr, M. (2007). Working Capital Management and Profitability- Case of Pakistan Firms. International Review of Business Research Papers, Vol. 3, No. 1, pp. 279- 300.

[58]. Rasheed O.A. (2010). Interest Rate Determinants in Nigeria. International Journal of Finance and Economics 2(3):1-12

[59]. Sayedi, S.(2013). Bank Specific, Industrial Specific and Macroeconomic Determinants of Banks' Profitability in Nigeria. Journal of Finance.

[60]. Stiglitz, J.E. and Weiss, A. (1981). Credit Rationing in Market with Imperfect Information. The American Economic Review vol71, No 3

[61]. Teruel, P. J. G. and Solano, P. M. (2006). Effect of Working Capital Management on SME Profitability, Retrieved on 15/03/2016 from http://papers.ssrn.com/sol13/papers.cfm?abstract id 931591.

[62]. Udeh S.N. (2015). Impact of Monetary Policy Instruments on Profitability of Commercial Banks in Nigeria: Zenith Bank Experience. Research Journal of Finance and Accounting www.iiste.org ISSN 2222-1697 (Paper) ISSN 2222-2847 (Online) Vol.6, No.10, 2015. Available on www.iiste.org.

[63]. Uchendu, O. (1995). Monetary Policy and the Performance of Commercial Banks in Nigeria. Central Bank of Nigeria Economic Review.

[64]. Victor (2013). Effect of Bank Lending Rate on the Performance of Nigerian Deposit Bank. International Journal of Business and Management Review. Vol 1.pp 34-43

[65]. Wainaina (2013). Effect of macroeconomic factors on Commercial Banks Lending to Agricultural Sector in Kenya. MBA Project University of Nairobi.

[66]. Wensheng, P., Lai, K., Leung, F. and Shu, C. (2002). Impact of Interest Rates Shocks on the Performance of Banking Sector. Hong Kong: Hong Kong Monetary Authority.

[67]. Were, M., Kamau, A., Sichei, M., Kiptui, M., (2013). A theoretical framework for Kenya's central bank macro econometric model. Africa growth initiative working paper

[68]. Were, R. and Wambua, S. (2013). Determinants of Interest Rates Spread. Nairobi, Kenya: Kenya Institute for Public Policy Research and Analysis. 